\title{
Respon Pertumbuhan dan Kualitas Hasil Beberapa Varietas Tomat pada Berbagai Frekuensi Penyiraman
}

Cicilia Tri Kusumastuti ${ }^{a}$ dan Ardiyanta ${ }^{b}$

${ }^{a}$ Fakultas Pertanian, Universitas PGRI Yogyakarta email: astyabady@yahoo.com

${ }^{b}$ Fakultas Pertanian, Universitas PGRI Yogyakarta

\section{Article Info}

\section{Article history:}

Received 8 November 2018

Received in revised form 19 Desember 2018 Accepted 25 Januari 2019

DOI:

https://doi.org/10.32938/sc.v4i01.57

Keywords:

Varietas

Tomat

Penyiraman

\section{Abstrak}

Penelitian tentang respon pertumbuhan dan kualitas hasil beberapa varietas tomat pada berbagai Frekwnsi penyiraman telah dilakukan pada bulan Mei - Agustus 2016 di Greenhouse Fakultas Pertanian Universitas PGRI Yogyakarta. Rancangan yang digunakan dalam penelitian ini adalah Rancangan Acak Lengkap Kelompok (RALK) yang terdiri dari dua faktor dan diulang sebanyak tiga kali. Faktor pertama adalah frekuensi penyiraman yang terdiri dari empat aras (setiap hari, 2 hari sekali, 4 hari sekali dan 8 hari sekali), sedangkan faktor kedua adalah varietas (Tymoti, Servo dan Betavila). Parameter yang diamati meliputi tinggi tanaman, klorofil daun, ber at kering sedangkan parameter pengamatan kualitas hasil meliputi fruitset, jumlah buah per tanaman, berat buah per tanaman, diameter buah, kekerasan buah, kematangan buah dan kadar vitamin C. Hasil penelitian menunjukkan bahwa tidak terjadi interaksi antara frekuensi penyiraman dengan varietas terhadap pertumbuhan dan kualitas hasil tanaman tomat. Frekuensi penyiraman setiap hari berpengaruh terhadap tingoi tanaman, klorofil daun, berat kering tanaman, fruitset, jumlah buah per tanaman dan berat buah per tanaman serta kandungan vitamin C. Varietas Betavila memberikan hasil yang terbaik daripada varietas tomat yang lain.

\section{Pendahuluan}

Tomat (Lycopersicum esculetum Mill.) merupakan salah satu komoditas hortikultura yang mempunyai nilai ekonomis tinggi. Tomat mengandung karotin yang berfungsi sebagai pembentuk provitamin A dan lycopen yang mampu mencegah kanker. Hal ini menyebabkan penggunaannya cukup tinggi dan mempunyai prospek cerah dalam upaya untuk meningkatkan kesejahteraan hidup petani serta dapat dijadikan sebagai komoditas multi manfaat yang komersiil. (Wiryanto, 2007)

Meningkatnya permintaan tomat membuat petani selalu berupaya untuk meningkatkan produksi tanaman tomat. Peningkatan produksi tidak hanya dari segi kuantitasnya tetapi juga dari segi kualitasnya. Tomat yang berkualitas baik yang banyak diminati oleh konsumen atau masyarakat sedangkan untuk criteria kualitas hasil tomat sangat beragam tergantung kebutuhan dari konsumen (Setyorini, dkk., 2009). Salah satu upaya untuk mendukung pengembangan agribisnis tanaman tomat adalah dengan penyediaan air yang mencukupi selama pertumbuhan. Air merupakan komponen penting bagi keberlangsungan berbagai proses fisiologi tanaman antara lain penyerapan unsur hara dan fotosintesis sehingga kekurangan air dapat menghambat pertumbuhan dan menurunkan hasil tanaman (Grant dkk., 1989). Untuk memenuhi kebutuhan air bagi tanaman dan menjaga ketersediaan air dalam tanah dapat dilakukan dengan penyiraman.

Selain dengan menjaga ketersediaan air selama pertumbuhan penggunaan varietas yang unggul juga dapat meningkatkan hasil tanaman tomat. Varietas unggul tomat mempunyai kelebihan sifat antara lain daya hasil tinggi, mempunyai bentuk, ukuran dan warna yang seragam serta memiliki ketahanan terhadap serangan hama dan penyakit (Siregar dkk., 2010).

\section{Metode}

Penelitian tentang respon pertumbuhan dan kualitas hasil beberapa varietas tomat pada berbagai frekuensi penyiraman telah dilakukan pada bulan Mei - Agustus 2016 di Greenhouse Fakultas Pertanian Universitas PGRI Yogyakarta. Bahan yang digunakan dalam penelitian ini adalah tomat varietas Tymoti, Servo dan Betavila. Penelitian ini menggunakan Rancangan Acak Kelompok Lengkap (RAKL) yang terdiri dari dua faktor dan diulang sebanyak tiga kali. Faktor pertama adalah frekuensi penyiraman yang terdiri dari empa aras (setiap hari, 2 hari sekali, 4 hari sekali dan 8 hari sekali), sedangkan fakto kedua adalah varietas (Tymoti, Servo dan Betavila).Untuk mengetahui respon pertumbuhan, parameter yang diamati meliputi tinggi tanaman, klorofil daun diukur dengen menggunakan klorofil meter SPAD, berat kering tanaman sedangkan kualitas hasil parameter pengamatannya meliputi fruitset diperoleh dengan menghitung jumlah buah yang ada dibagi jumlah bunga pada tanaman dikalikan $100 \%$, jumlah buah per tanaman dengan menghitung jumlah buah yang ada pada tanaman, berat buah per tanaman dengan menimbang seluruh buah pada tanaman, diameter buah diukur dengan menggunakan jangka sorong, kekerasan buah diukur melalui penekan kekerasan buah yang dihubungkan ke komputer (Newton/ $\mathrm{mm}^{2}$ ), kematangan buah ditentukan berdasarkan klasifikas warna yang sudah dimodifikasi untuk tomat dari USDA 1975 (Cahyono 1998 dalam Setyorini 2009) dan kadar vitamin C diperoleh dengan menggunakan metode titrasi iodin. Buah tomat sebanyak $20 \mathrm{~g}$ dihaluskan, disaring dan volume diencerkan sampai $200 \mathrm{ml}$, kemudian diambil sampel sebanyak $20 \mathrm{ml}$ dan $2 \mathrm{ml}$ larutan amilum 1\%. Sampel dititrasi dengan 0,001 N larutan iodin sampai larutan menjadi biru. Setiap $1 \mathrm{ml} 0,01 \mathrm{~N}$ iodin=0,88 mg vitamin $\mathrm{C}$. Kandungan vitamin $\mathrm{C}$ per $100 \mathrm{~g}$ bahan dihitung dengan persamaan penghitungan kadar vitamin $\mathrm{C}$ metode iodine. Data yang diperoleh dianalisis menggunakan analysis of variance dan dilanjutkan dengan uji jarak berganda Duncan (Duncan's Multiple Range Test) pada jenjang nyata $5 \%$ (Gomez, dkk, 2007).

\section{Hasil dan Pembahasan}

\subsection{Tinggi Tanaman}

Tinggi tanaman merupakan salah satu parameter yang sering diamati untuk mengukur pengaruh perlakuan terhadap pertumbuhan tanaman. Hasil analisis menunjukkan bahwa perlakuan frekuensi penyiraman berpengaruh nyata terhadap tinggi tanaman. Tabel 1. menunjukkan bahwa frekuensi penyiraman setiap hari memberikan rerata tertinggi $(52,88)$ dan berbeda nyata dengan perlakuan 2, 4 dan 6 hari sekali. Pemberian air yang kurang menyebabkan suplai air ke dalam tubuh tanaman juga menurun sehingga proses metabolisme dalam tubuh tanaman akan terhambat dan mengakibatkan pertumbuhan tanaman juga terhambat. Ketersediaan air dalam tanah merupakan salah satu faktor lingkungan yang sangat berpengaruh terhadap pertumbuhan dan produksi tanaman (Dzajul 2010 dalam Jumawati.,dkk 2014).

Tabel 1. Rerata Tinggi Tanaman, Klorofil Daun, dan Berat Kering Tanaman

\begin{tabular}{cccc} 
Perlakuan & $\begin{array}{c}\text { Tinggi Tanaman } \\
(\mathrm{cm})\end{array}$ & $\begin{array}{c}\text { Klorofil Daun } \\
(\text { Unit })\end{array}$ & $\begin{array}{c}\text { Berat } \\
\text { Kering } \\
\text { Tanaman } \\
(\mathrm{g})\end{array}$ \\
\hline Frekuensi Penyiraman & & & \\
Setiap hari & $52,88 \mathrm{a}$ & $33,31 \mathrm{a}$ & $31,33 \mathrm{a}$ \\
2 Hari & $42,14 \mathrm{~b}$ & $27,24 \mathrm{~b}$ & $31,10 \mathrm{a}$ \\
4 Hari & $40,93 \mathrm{bc}$ & $28,51 \mathrm{~b}$ & $30,60 \mathrm{ab}$ \\
6 Hari & $35,72 \mathrm{c}$ & $26,07 \mathrm{c}$ & $27,38 \mathrm{~b}$ \\
\hline Varietas & & & \\
Tymoti & $43,10 \mathrm{p}$ & $27,48 \mathrm{p}$ & $26,43 \mathrm{p}$ \\
Servo & $43,83 \mathrm{p}$ & $29,76 \mathrm{p}$ & $28,32 \mathrm{q}$ \\
Betavila & $42,82 \mathrm{p}$ & $29,11 \mathrm{p}$ & $35,53 \mathrm{q}$ \\
\hline
\end{tabular}

Keterangan : Angka pada kolom dan baris diikuti huruf menunjukkan tidak berbeda pada tingkat nyata $(\alpha)$ menurut uji D (+) : Terjad inetraksi antara faktor frekuensi penyiraman dengan varietas tanaman tomat.

\subsection{Klorofil Daun}

Klorofil daun berkaitan erat dengan proses fotosintesis pada tanaman. Biosintesis klorofil dan pembentukan proto klorofil sangat dipengaruhi oleh ketersediaan air (Salisbury \& Ross, 1992). Hasil analisis ragam menunjukkan bahwa frekuensi penyiraman berpengaruh nyata terhadap klorofil daun sedangkan varietas tidak berpengaruh nyata terhadap klorofil daun. Frekuensi penyiraman setiap hari menunjukan klorofil daun tertinggi $(33,31)$ dan berbeda nyata dengan perlakuan 2, 4 dan 6 hari sekali (Tabel 1). Ketersediaan air yang rendah mengakibatkan transport dari ammonium terhambat. Kadar air dalam tanah yang rendah menyebabkan laju fotosintesis terhambat dan menyebabkan terjadinya penurunan sintesis klorofil. Kadar air yang rendah juga menyebabkan peningkatan temperatur dan transpirasi yang dapat menyebabkan disintegrasi klorofil (Hendriyanti \& Setiani, 2009).

\subsection{Berat Kering Tanaman}

Berat kering tanaman menunjukkan kadar biomassa tanaman. Selain itu berat kering tanaman juga dapat menunjukkan translokasi hasil fotosintesis ke seluruh bagian tanaman (Gardner dkk., 2008). Tabel 1. menunjukkan bahwa frekuensi penyiraman dan macam varietas berpengaruh nyata terhadap berat kering tanaman meskipun tidak terjadi interaksi antar keduanya. Bobot kering terendah $(27,38)$ diperoleh pada frekuenasi penyiraman 6 hari sekali. Rendahnya berat kering tanaman ini kemungkinan disebabkan oleh penurunan laju fotosintesis sehingga mengakibatkan menurunnya asimilasi $\mathrm{CO}_{2}$ karena tertutupnya stomata. Ketersediaan air yang rendah dapat menurunkan pertumbuhan vegetatif dan hasil panen dengan cara mengurangi pertumbuhan daun dan menurunnya fotosintesis daun yang mengakibatkan fotosintesis tajuk juga menurun (Gardner dkk., 2008)

Varietas betavila memberikan rerata tertinggi $(35,53)$ dan berbeda nyata dengan varietas Tymoty (Tabel 1). Masing-masing varietas mempunyai susunan genetik yang berbeda. Perbedaan genetik pada tanaman menyebabkan perbedaan dalam pembentukan enzim yang berperan sebagai katalisator dalam proses metabolisme tanaman diantaranya adalah proses fotosintesis sehingga akan mempengaruhi fotosintat yang dihasilkan (Lehninger, 1997) 


\subsection{Fruitset dan jumlah buah per tanaman}

Frekuensi penyiraman berpengaruh nyata terhadap fruitset dan jumlah buah pertanaman. Frekuensi penyiraman setiap hari memberikan rerata tertinggi (Tabel 2). Fase pembungaan merupakan periode kritis. Apabila tanaman tomat pada saat fase pembungaan mengalami cekaman atau kekurangan air dalam jangka waktu yang panjang dapat menyebabkan gangguan atau hambatan pada stadium awal pertumbuhan dan kerontokan bunga. Hal ini akan berpengaruh terhadap jumlah buah yang terbentuk (Pudjiatmoko, 2008).

\subsection{Berat Buah per Tanaman dan Diameter Buah}

Pertumbuhan dan pembentukan ukuran buah sangat dipengaruhi oleh jumlah air yang tersedia. Frekuensi penyiraman berpengaruh nyata terhadap berat buah per tanaman, tetapi tidak berpengaruh nyata diameter buah. Frekuensi penyiraman setiap hari memberikan rerata berat buah pert tanaman dan diameter buah tertinggi (Tabel 2). Kekurangan air dapat menyebabkan penurunan aktifitas fotosintesis sehingga jumlah fotosintat yang dihasilkan juga berkurang. Hal ini dapat berpengaruh terhadap menurunnya jumlah buah dan bobot buah ( Desmarina dkk., 2009).

Selain frekuensi penyiraman varietas juga berpengaruh nyata terhadap berat buah per tanaman dan diameter buah. Tabel 2 menunjukkan bahwa varietas Betavila memberikan rerata berat buah per tanaman dan diameter buah tertinggi. Hal ini disebabkan genetis dari varietas Betavila yang mempunyai potensi hasil dan berat buah yang tinggi yaitu antara $80-90$ gram.

Tabel 2. RerataFruitset, Jumlah buah per tanaman, Berat buah per tanaman dan Diameter buah

\begin{tabular}{|c|c|c|c|c|}
\hline Perlakuan & $\begin{array}{l}\text { Fruitset } \\
(\%)\end{array}$ & $\begin{array}{l}\text { Jumlah buah } \\
\text { per tanaman } \\
\text { (buah) }\end{array}$ & $\begin{array}{l}\text { Berat buah per } \\
\text { tanaman } \\
(\mathrm{g})\end{array}$ & $\begin{array}{l}\text { Diameter buah } \\
(\mathrm{cm})\end{array}$ \\
\hline \multicolumn{5}{|c|}{ Frekuensi Penyiraman } \\
\hline Setiap hari & $45,00 \mathrm{a}$ & $31,15 \mathrm{a}$ & 526,77 a & $4,07 \mathrm{a}$ \\
\hline 2 Hari & $43,85 \mathrm{a}$ & $30,74 \mathrm{a}$ & $411,00 \mathrm{~b}$ & $3,53 \mathrm{a}$ \\
\hline 4 Hari & $40,54 \mathrm{~b}$ & $25,64 \mathrm{~b}$ & $388,22 \mathrm{bc}$ & $3,66 \mathrm{a}$ \\
\hline 6 Hari & $39,87 \mathrm{~b}$ & $24,71 \mathrm{~b}$ & 290.22 c & $2,84 \mathrm{a}$ \\
\hline \multicolumn{5}{|l|}{ Varietas } \\
\hline Tymoti & $44,54 \mathrm{p}$ & $30,59 \mathrm{p}$ & $351,83 \mathrm{q}$ & $3,64 \mathrm{p}$ \\
\hline Servo & $40,86 \mathrm{q}$ & $27,49 \mathrm{p}$ & $382,91 \mathrm{q}$ & $2,60 \mathrm{q}$ \\
\hline Betavila & $41,54 \mathrm{q}$ & $26,11 \mathrm{p}$ & $477,41 \mathrm{p}$ & $4,33 \mathrm{r}$ \\
\hline
\end{tabular}

Keterangan : Angka pada kolom dan baris diikuti huruf yang sama menunjukkan tidak berbeda pada nyata $(\alpha) 5 \%$ menurut uji DMRT $(+)$ : Terjad inetraksi antara faktor frekuensi penyiraman dengan varietas tanaman tomat.

\subsection{Kekerasan Buah, Kematangan buah dan Vitamin C}

Tabel 3. menunjukkan bahwa perlakuan frekuensi penyiraman tidak berpengaruh nyata terhadap kekerasan dan kematangan buah. Frekuensi penyiraman hanya berpengaruh nyata terhadap kandungan vitamin $\mathrm{C}$ dalam buah. Rerata vitamin $\mathrm{C}$ terendah diperoleh padafrekuensi penyiraman 6 hari sekali. Hal ini disebabkan karena ketersediaan air yang terbatas dapat mempengaruhi penyerapan unsur hara. Salah satu unsur hara yang berperan penting dalam metabolism tanaman adalah Nitrogen. Wagner dkk., dalam Marchner (1986) dalam Wijayani dkk., (2005) menyatakan bahwa pemasokan mineral, terutama nitrogen akan berpengaruh terhadap aktivitas sitokinin pada akar. Nitrogen yang tidak terserap oleh akar keberadaannya dalam tanaman akan rendah dan mempengaruhi aktivitas sitokinin. Penurunan aktivitas sitokinin ini menyebabkan terhambatnya metabolisme protein di daun karena sitokinin berperan sebagai regulator dalam pembentukan senyawa protein tanaman. Sebagian dari protein selanjutnya akan disintesis menjadi vitamin $\mathrm{C}$ pada buah.

Tabel 3. Rerata Kekerasan buah, Kematangan buah dan Vitamin C

\begin{tabular}{lccc}
\hline Perlakuan & $\begin{array}{c}\text { Kekerasan buah } \\
\left(\text { Newton } / \mathrm{mm}^{2}\right)\end{array}$ & Kematangan buah & $\begin{array}{c}\text { Vitamin C } \\
(\mathrm{mg} / 100 \mathrm{~g})\end{array}$ \\
\hline Frekuensi Penyiraman & & \\
Setiap hari & $0,29 \mathrm{a}$ & $4,07 \mathrm{a}$ & $12,72 \mathrm{ab}$ \\
2 Hari & $0,31 \mathrm{a}$ & $3,53 \mathrm{a}$ & $14,59 \mathrm{a}$ \\
4 Hari & $0,24 \mathrm{a}$ & $3,66 \mathrm{a}$ & $10,83 \mathrm{bc}$ \\
6 Hari & $0,24 \mathrm{a}$ & $2,84 \mathrm{a}$ & $8,91 \mathrm{c}$ \\
\hline Varietas & & & \\
Tymoti & $0,21 \mathrm{p}$ & $2,35 \mathrm{p}$ & $10,87 \mathrm{p}$ \\
Servo & $0,21 \mathrm{p}$ & $2,40 \mathrm{p}$ & $11,98 \mathrm{p}$ \\
Betavila & $0,17 \mathrm{p}$ & $2,37 \mathrm{p}$ & $12,44 \mathrm{p}$ \\
\hline
\end{tabular}

Keterangan : Angka pada kolom dan baris diikuti huruf yang sama menunjukkan tidak berbeda pada tingkat nyata $(\alpha) 5 \%$ menurut uji DMRT $(+$ : Terjadi inetraksi antara faktor frekuensi penyiraman dengan varietas tanaman tomat.

\section{Simpulan}

Frekuensi penyiraman setiap hari memberikan pengaruh yang terbaik terhadap pertumbuhan dan kualitas hasil tanaman tomat. Sedangkan untuk varietas tomat yang memberikan respon pertumbuhan dan kualitas hasil yang terbaik adalah Betavila.
Pustaka

Desmarina R, Adiwirman, Widodo. 2009. Respon Tanaman Tomat Terhadap Frekuensi da taraf Pemberian Air Terhadap Pertumbuhan dan Perkembangan Tanaman Tomat. Seminar Fakultas Pertanian IPB. Bogor.

Gardner, F.P., R.B. Pearce, dan R.L. Mitchell. 2008. Physiology of Crop Plants (FisiologiTanaman Budidaya, alih bahasa: Herawati Susilo, pendamping: Subiyanto). Penerbit Universitas Indonesia (UI-Press), Jakarta.

Gomez, K.A. dan A.A. Gomez, 2007. Prosedur Statistik Untuk Penelitian Pertanian. Edisi Kedua. UI Press. Jakarta.

Grant, R.F., B.F. Jackson, J.R. Kiniry, G.F. Arkin. 1989. Water Deficit Timing Effects on Yield Components in Maize. Agronomi Journal (81): 61 - 65.

Hendriyanti, I.S dan N Setiani, 2009. Kandungan Klorofil dan Pertumbuhan Kacang Panjang (Vigna sinensis) pada Tingkat Penyediaan Air yang berbeda. J. Sains \& Mat 17 (3): 145 - 150.

Jumawati R, A.T Sakya, M. Rahayu,. 2014. Pertumbuhan Tomat pada Frekuensi Pengairan yang Berbeda. Agrosains 16 (1): 13 - 18 .

Lehninger, A. L., 1997. Dasar-dasar Biokimia . Jilid I. Jakarta: Erlangga.

Pudjiatmoko, 2008. Budidaya Tomat (Lycopersicon esculentum Mill). http:www.nusaku.com.

Salisbury, F. B. dan C. W. Ross, 1992. Fisiologi Tumbuhan. Terjemahan dari Plant Fisiology oleh D.R. Lukman dan Sumaryono. Institut Teknologi Bandung Press. Bandung

Setyorini, D. Indradewa, E. Sulistyaningsih, 2009. Kualitas Buah Tomat pada Pertanaman dengan Mulsa Plastik Berbeda. J. Hort. 19 (4): 407 - 412.

Siregar, L. A. M., Rosmayati Dan Julita, 2010. Uji Beberapa Varietas Tomat (Lycopersicum esculentum Mill) Jurnal Ilmu Pertanian KULTIVAR 4 (2) $4-5$.

Wijayani A, Widodo W, 2005. Usaha Meningkatkan Kualitas Beberapa Varierat Tomat Dengan Sistem Budidaya Hidroponik. Ilmu Pertanian Vol.12 No. 1. Hal $77-83$.

Wiryanto, B.T.W., 2007. Bertanam Tomat. Agro Media Pustaka. Jakarta. 